\title{
SIGNIFICANCE OF SMALL TOWNS IN THE PROCESS OF URBANISATION OF THE WIELKOPOLSKA REGION (POLAND)
}

\author{
Barbara Konecka-Szydłowska ${ }^{1}$
}

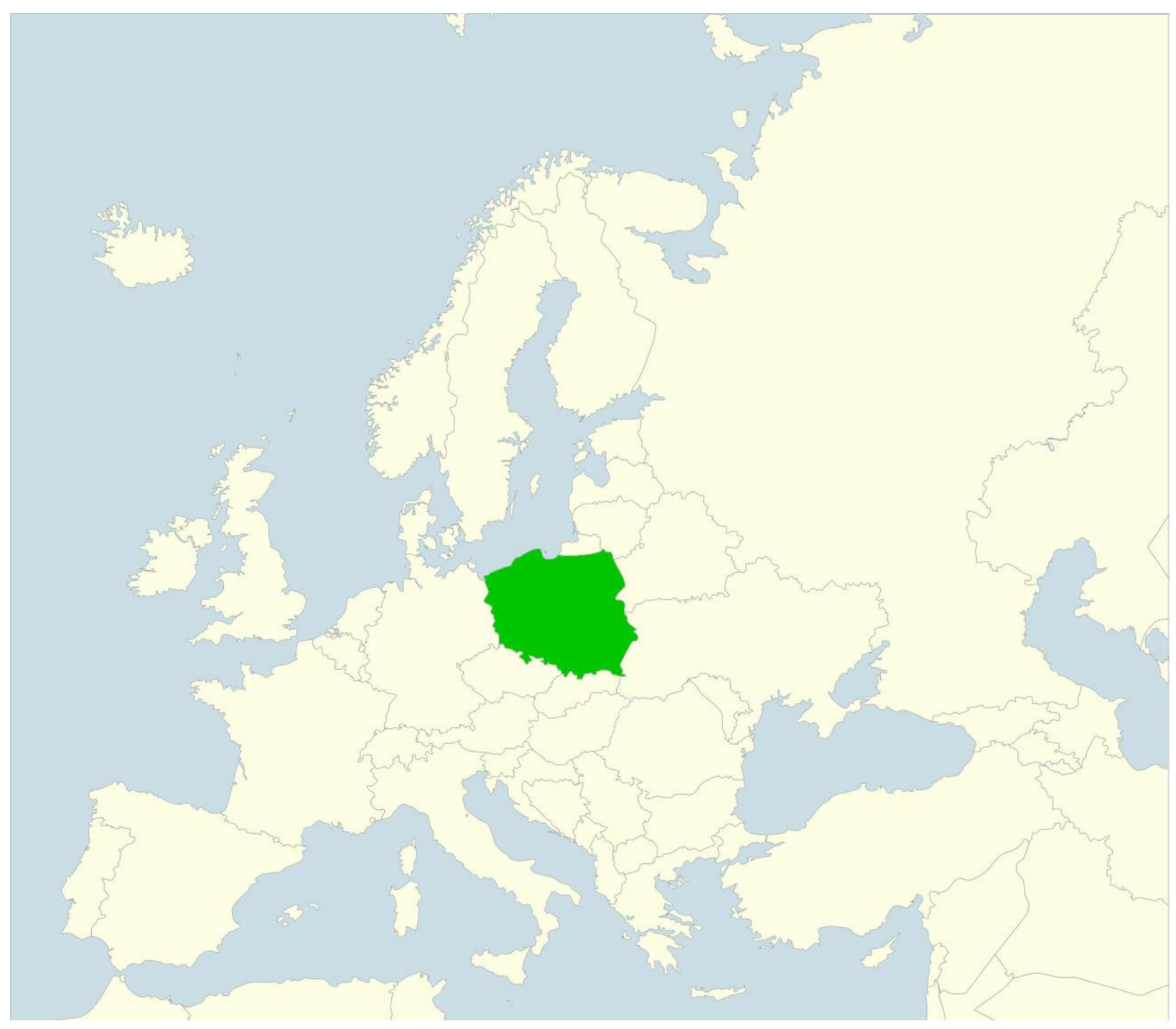

1 Dr. Barbara Konecka-Szydłowska, Institute of Socio-Economic Geography and Spatial Management of Adam Mickiewicz University, ul. Bogumiła Krygowskiego 10, 61-680 Poznań; e-mail: bako@amu.edu.pl 


\begin{abstract}
A study is made of the significance of small towns in the process of urbanisation of Wielkopolska, a region situated in the western part of Poland. The analysis is conducted in both, a dynamic and a static approach, and covers two aspects of urbanisation: demographic and spatial. The basic period examined embraces the years 2000-2015. What is visible in the set of Wielkopolska towns is the depopulation of its core city, Poznań, accompanied by an increase in the population of small units located in its suburban zone. There is an upward tendency in the population number also in selected size classes of small Wielkopolska towns, which demonstrates that in this case we cannot speak of a crisis of small towns since they play an important role in the process of urbanisation of the region. In the recent years, increasingly important in this process, especially at the local level, has been the appearance of new towns set up as a result of the restitution of municipal rights.
\end{abstract}

Key words: urbanisation, small towns, Wielkopolska voivodeship, Poland

\begin{abstract}
Abstrakt: Znaczenie małych miast w procesie urbanizacji województwa wielkopolskiego (Polska). W opracowaniu bada się znaczenie małych miast w procesie urbanizacji województwa wielkopolskiego, położonego w zachodniej części Polski. Analiza prowadzona jest zarówno w ujęciu dynamicznym jak i statycznym i obejmuje dwa aspekty urbanizacji demograficzny i przestrzenny. Zasadniczy okres badań stanowią lata 2000-2015. Uzyskane wyniki pozwalają stwierdzić, że w zbiorze miast województwa wielkopolskiego jest widoczna depopulacja miasta głównego Poznania przy wzroście liczby mieszkańców małych miast położonych w strefie podmiejskiej. Tendencja wzrostowa liczby ludności utrzymuje się również w wybranych klasach wielkościowych małych miastach, co świadczy o tym, że nie można w tym przypadku mówić o kryzysie miast małych, które odgrywają istotną rolę w procesie urbanizacji województwa wielkopolskiego. W ostatnich latach w procesach urbanizacji województwa wielkopolskiego, zwłaszcza na poziomie lokalnym, wzrasta znaczenie nowych miast utworzonych w wyniku procesów restytucji.
\end{abstract}

Słowa kluczowe: urbanizacja, małe miasta, województwo wielkopolskie, Polska

\title{
1. Introduction
}

The notion of urbanisation can be considered in its two basic meanings. In a dynamic approach, urbanisation is understood as a process of change manifesting itself in the development of urban settlement, and in a static approach it is defined as the state of the development of towns, or in other words, the level of urbanisation of a given area. This dualism in the understanding of urbanisation also shows in measures commonly employed to assess it. In the dynamic approach, they include growth in the number of towns and in the proportion of the urban population, and in the static approach - the proportion of the urban population. Because of the complexity of urbanisation, its four basic aspects are considered in order to systematise the research: demographic, connected with an increase in the share of the urban population in the total population figure; spatial, as expressed by an increase in the number of towns and urbanised spaces; economic, or an increase in the proportion of the population working in nonagricultural jobs; and social, involving the adoption by people of an urban lifestyle (Maik, 1992; Pacione, 2005; Szymańska, 2007, 2009; Jakóbczyk-Gryszkiewicz, 2012; Szmytkie, 2014).

The chief goal of this paper is to determine the significance of small towns in the process of urbanisation of Wielkopolska, a region situated in the western part of Poland. The analysis is conducted in both, a dynamic and a static approach, and covers two aspects of urbanisation: demographic and spatial. The reason why no analysis is offered of the economic aspect of urbanisation is mostly the unavailability of comparable data about the number of economic 
entities and the working population in the towns of Wielkopolska voivodeship in the years 20002015 , which is an effect of changes in the PKD classification. Also, there is no analysis of the social aspect of urbanisation, which by its very nature is hard to measure because of great problems with empirical indicators. The basic period studied embraces the years 2000-2015.

The chief goal is attained via specific goals that can be presented in the form of the following cognitive questions:

1. What is the urbanisation level of Wielkopolska voivodeship seen against Poland's regional system?

2. What are the characteristics of the urban settlement network of Wielkopolska voivodeship?

3. What is the population situation in Wielkopolska towns, especially small ones?

4. How do natural increase and migration movement affect the natural change in towns?

5. Does the spatial location of small towns influence their population situation?

6. What role in the urbanisation of Wielkopolska is played by new towns?

Polish towns include big, medium-sized and small ones. The formal criterion on the basis of which the set of small towns is distinguished is the population. Therefore there appears the problem of establishing the upper limit, i.e. the maximum number of residents above which a town will be assigned to another size class. The opinion predominating in Polish scientific literature, statistical breakdowns and comparative analyses is that small towns are units with up to 20 thousand residents, and this is the assumption adopted in this paper (Czyż, 2000; Kwiatek-Sołtys, 2004; Szymańska and Grzelak-Kostulska 2005; Zuzańska-Żyśko, 2006; Heffner, 2008; Konecka-Szydłowska, 2003, 2011; Konecka-Szydłowska, Zuzańska-Żyśko and Szmytkie 2010; Runge and Kwiatek-Soltys 2011; statistical registers of the Central Statistical Office). Very often an analogous criterion of defining small towns is applied in urban studies conducted in other European states, e.g. the Czech Republic (Vaishar and Zapletalová 2009), Estonia (Leetmaa, Nuga and Org 2013), France (Mainet, 2015), and Germany (Burdack and Kriszan 2013; Kühn 2015).

\section{Wielkopolska voivodeship in comparison with other Polish regions}

In 2015 there were 915 towns in Poland, more than 30\% of which (268) were concentrated in only three voivodeships: Wielkopolska, Lower Silesia and Mazovia, while the remaining 13 voivodeships accounted for less than $70 \%$ of towns (647). Wielkopolska has the biggest number of towns. In 2015 there were 111 towns here, or $12.2 \%$ of their total number in the country. The relatively great density of the urban settlement network of Wielkopolska voivodeship is largely due to historical factors. The western parts of Poland (including Wielkopolska) are characterised by a much greater density of towns than its eastern regions due to the historical processes of urbanisation diffusion, which was the direction it took on the Polish lands. Later, when the Polish lands were partitioned among three neighbouring powers (mostly the 19th century), the Prussian authorities generally honoured the municipal rights obtained, unlike the rather common degradation of towns in the Russian-occupied Congress Kingdom (Poland's eastern parts). Today the largest number of towns are located in the voivodeships of Wielkopolska and Lower Silesia (Krzysztofik 2006, Jażdżewska 2006, Schmidt and Matykowski 2007, Najgrakowski 2009, Węcławowicz 2010).

Wielkopolska is a region showing a high level of urbanisation as measured by the total number of towns, but with a relatively low proportion of the urban population, at $55.2 \%$, while the mean for Poland is $60.4 \%$. This is due to the numerical predominance of small towns, with up to 20 thousand residents, that make up $82 \%$ of the voivodeship's urban units and $13.3 \%$ of the country's small towns (Table 1).

In terms of the dynamics of the urban population, Wielkopolska shows relative stability in its demographic processes. At $98.8 \%$, its index of urban population dynamics in the years 2000 2014 was close to the national average. This relatively favourable population situation of the Wielkopolska towns is corroborated by the region's lowest proportion of depopulating towns: a mere $7.4 \%$ in the years $1990-2010$ as against $30 \%$ for the country as a whole. There were 
only eight Wielkopolska towns in this set, including the centrally located city of Poznań, the voivodeship capital. In this case one cannot speak of typical shrinkage because its depopulation is due to the loss of residents in favour of the neighbouring units associated with the city functionally, i.e. with the process of suburbanisation. The other depopulating towns are small units located in the peripheral areas of Wielkopolska (Jaroszewska and Stryjakiewicz 2014).

Tab 1. Level of urbanisation in Poland by voivodeship (1 Jan. 2015).

\begin{tabular}{|c|c|c|c|c|c|c|c|c|}
\hline 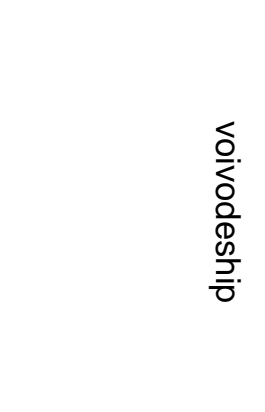 & 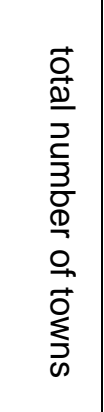 & 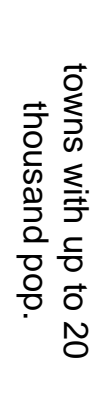 & 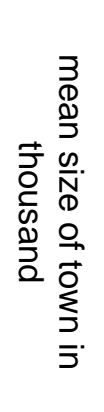 & 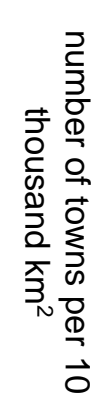 & 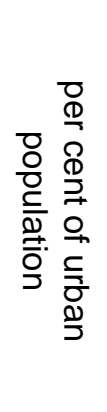 & 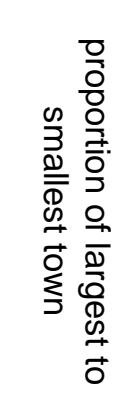 & 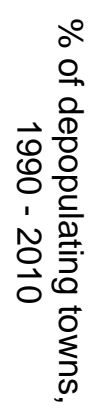 & 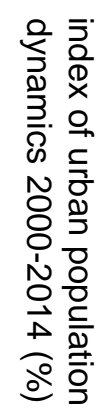 \\
\hline Poland & 915 & 693 & 24.4 & 29 & 60.4 & $\begin{array}{r}353.8 \text { - } \\
\text { mean }\end{array}$ & 30.0 & 98.1 \\
\hline Lower Silesia & 91 & 72 & 22.1 & 45 & 69.4 & 346.9 & 56.8 & 96.7 \\
\hline $\begin{array}{l}\text { Kujavia- } \\
\text { Pomerania }\end{array}$ & 52 & 44 & 24.0 & 29 & 60.1 & 253.1 & 12.0 & 96.9 \\
\hline Lublin & 43 & 33 & 23.1 & 17 & 46.2 & 246.6 & 27.7 & 96.4 \\
\hline Lubuska Land & 42 & 36 & 15.7 & 30 & 63.1 & 107.5 & 27.5 & 98.7 \\
\hline Łódź & 44 & 28 & 35.9 & 24 & 63.4 & 348.8 & 42.5 & 92.6 \\
\hline Małopolska & 61 & 47 & 26.8 & 40 & 48.7 & 458.7 & 22.4 & 100.3 \\
\hline Mazovia & 86 & 61 & 39.8 & 24 & 64.2 & 1884.3 & 9.0 & 103.7 \\
\hline Opole & 35 & 29 & 14.8 & 37 & 52.1 & 69.4 & 78.8 & 92.3 \\
\hline Subcarpathia & 51 & 41 & 17.2 & 28 & 41.2 & 128.8 & 15.9 & 102.9 \\
\hline Podlasie & 40 & 32 & 18.0 & 19 & 60.4 & 292.8 & 24.2 & 101.5 \\
\hline Pomerania & 42 & 27 & 35.4 & 23 & 65.1 & 345.6 & 25.0 & 100.3 \\
\hline Silesia & 71 & 34 & 49.9 & 57 & 77.4 & 162.8 & 61.0 & 94.0 \\
\hline $\begin{array}{l}\text { Świętokrzyska } \\
\text { Land }\end{array}$ & 32 & 26 & 17.6 & 27 & 44.8 & 206.3 & 60.0 & 94.4 \\
\hline $\begin{array}{l}\text { Warmia- } \\
\text { Mazuria }\end{array}$ & 49 & 38 & 14.4 & 20 & 59.3 & 95.6 & 23.9 & 99.3 \\
\hline Wielkopolska & 111 & 91 & 17.2 & 37 & 55.2 & 382.3 & 7.4 & 98.8 \\
\hline $\begin{array}{l}\text { West } \\
\text { Pomerania }\end{array}$ & 65 & 54 & 18.1 & 28 & 68.6 & 332.1 & 20.0 & 99.5 \\
\hline
\end{tabular}

Source: Area and population in the territorial pattern in 2015, Central Statistical Office, Warsaw, http://shrinkage.amu.edu.pl/publikacje.html

In Wielkopolska the density of towns is relatively high, at 37 per 10 thousand per $\mathrm{km}^{2}$, higher than the national average of 29 towns. This figure does not determine the urban population in a decisive way because of wide differences in the size of towns. The high density of towns in the region results from a well-developed network of small towns accompanied by a deficiency of larger cities that assemble more people than a lot of small units (Konecka-Szydłowska, 2009).

The mean population of a Wielkopolska town is only 17.2 thousand, markedly lower than the mean for Poland, at 24.4 thousand. The size relation of the largest city (Poznań) to its smallest town (Dobra) does not depart much from the national average (Table 1). 


\section{Urban settlement network in Wielkopolska voivodeship}

The level of population development of Wielkopolska is determined by the population size and its dynamics. With its 3.4 million residents (2014), Wielkopolska belongs to voivodeships with a medium-sized population (its population density is 116 persons per $\mathrm{km}^{2}$, the national average being 123 persons per $\mathrm{km}^{2}$ ).

Strictly associated with the population size is the level of the region's urbanisation as determined by the number of towns and the proportion of town dwellers in the total population figure. In 2015 there were 111 towns in Wielkopolska that formed a polycentric system with five hierarchical levels (Strategy for the Development of Wielkopolska Voivodeship until 2020, Marshal's Office in Poznań, 17 Dec. 2012). At the top was the voivodeship capital, Poznań, a node of national significance, followed by supra-regional units: Kalisz and Ostrów Wielkopolski, regional ones: Gniezno, Konin, Leszno and Piła, and finally by poviat towns (28) and local units (76) (Fig. 2).

Clearly standing out in the Wielkopolska urban system is the sub-system of towns of the Poznań agglomeration (Poznań poviat). It includes 11 towns, i.e. the core city of Poznań performing the function of a node, and 10 towns in the zone of direct Poznań impact, closely connected with it functionally. Two of them, Luboń and Swarzędz, are medium-sized units, the other eight are small towns with under 20 thousand residents, including six with fewer than 10 thousand.

In terms of size, the regional system of Wielkopolska towns can be put into three classes: big towns (over 100 thousand residents), medium-sized ones (20 - 100 thousand) and small ones (up to 20 thousand) with a diversified internal structure. It should be emphasised that among the 111 Wielkopolska towns the class of big ones with the greatest socio-economic potential includes only two units: Poznań (545.7 thousand) and Kalisz (103.4 thousand). Together they account for $34 \%$ of the voivodeship's urban population. The class of medium-sized towns consists of 18 units inhabited by $36.5 \%$ of the voivodeship's urban population. In this class there are five towns in the size interval of 50-100 thousand, the other 13 having from 20 to 50 thousand residents. The class of small towns is the biggest, with 91 units, but it only accounts for $29.5 \%$ of the voivodeship's urban population. This class varies internally, with four subclasses: towns with a population of $10-20$ thousand, 5 - 10 thousand, 2 - 5 thousand, and up to 2 thousand. The largest group includes small units with 2 to 5 thousand residents, which account for less than 7\% of the urban population. In 2015 there were 41 such units in the region. The rate of the population of the largest of the small towns, Chodzież $(19,299)$, to the smallest one, Dobra $(1,427)$, is $13.5: 1$.

In the years 2000 - 2015 there were only small changes in the size of individual classes of towns, the largest having occurred in that of small towns, the number of which grew from 89 to 91. This increase was a result of granting municipal rights to two units: Dobrzyca (2014) and Chocz (2015). Over this period the population of small towns grew from 548,148 to 564,284 (the dynamics index of $102.9 \%$ ), which means that the proportion of the population of small towns in total urban population rose from $28.3 \%$ in 2000 to $29.5 \%$ in 2015 (Table 2).

The regularity of the size structure of Wielkopolska towns in terms of Zipf's rank-size rule ${ }^{2}$ is given by the exponent of contrasts in their size equal to 1.18. It shows the empirical distribution of the towns by size to be disturbed and discontinuous in the segment of medium-sized units, while its small-towns segment indicates their considerable over-representation. This means that the voivodeship's urban network has a somewhat disturbed size structure of towns (Fig. 1).

\footnotetext{
2 Zipf's (1949) rank-size model of towns takes the form of the equation: $\quad P_{j}=P_{1} j^{-a}$

where: $\mathrm{P}_{\mathrm{j}}$ is the population of the jth town, $\mathrm{P}_{1}$ is the population of the largest town (in our case, Poznań), $j$ is the rank of the jth town, and $a$ is the contrast exponent. In Zipf's model the system shows a balance of towns of various size classes (the exponent of contrasts in the size of towns $a=1$ ), which means their continuous and regular distribution. In the case of a deviation from the regular distribution, $a>1$, there is an over-representation of small towns, and with $a<1$, an over-representation of big cities.
} 
Tab 2. Population of Wielkopolska towns by size classes in 2000 and 2015.

\begin{tabular}{|c|c|c|c|c|c|c|c|}
\hline \multirow{2}{*}{$\begin{array}{l}\text { size class } \\
\text { of towns } \\
\text { [thousand] }\end{array}$} & \multicolumn{3}{|c|}{2000} & \multicolumn{3}{|c|}{2015} & \multirow{2}{*}{$\begin{array}{c}2000-2015 \\
\text { dynamics } \\
\text { of } \\
\text { population } \\
\text { number }\end{array}$} \\
\hline & $\begin{array}{l}\text { number } \\
\text { of towns }\end{array}$ & population & $\begin{array}{l}\text { per cent of } \\
\text { total urban } \\
\text { population }\end{array}$ & $\begin{array}{l}\text { number } \\
\text { of towns }\end{array}$ & population & $\begin{array}{l}\text { per cent of } \\
\text { total urban } \\
\text { population }\end{array}$ & \\
\hline over 100 & 2 & 692,358 & 35.8 & 2 & 649,053 & 34.0 & 93.7 \\
\hline $50-100$ & 5 & 364,415 & 18.8 & 5 & 357,936 & 18.7 & 98.2 \\
\hline $20-50$ & 13 & 331,204 & 17.1 & 13 & 340,949 & 17.8 & 102.9 \\
\hline $10-20$ & 17 & 253,153 & 13.1 & 18 & 264,300 & 13.8 & 104.4 \\
\hline $5-10$ & 22 & 153,342 & 7.9 & 21 & 150,386 & 7.9 & 98.1 \\
\hline $2-5$ & 39 & 122,337 & 6.3 & 41 & 132,139 & 6.9 & 108.0 \\
\hline under 2 & 11 & 19,316 & 1.0 & 11 & 17,459 & 0.9 & 90.4 \\
\hline total & 109 & $1,936,125$ & 100.0 & 111 & $1,912,222$ & 100.0 & 98.7 \\
\hline
\end{tabular}

Source: own calculations on the basis of the Central Statistical Office data

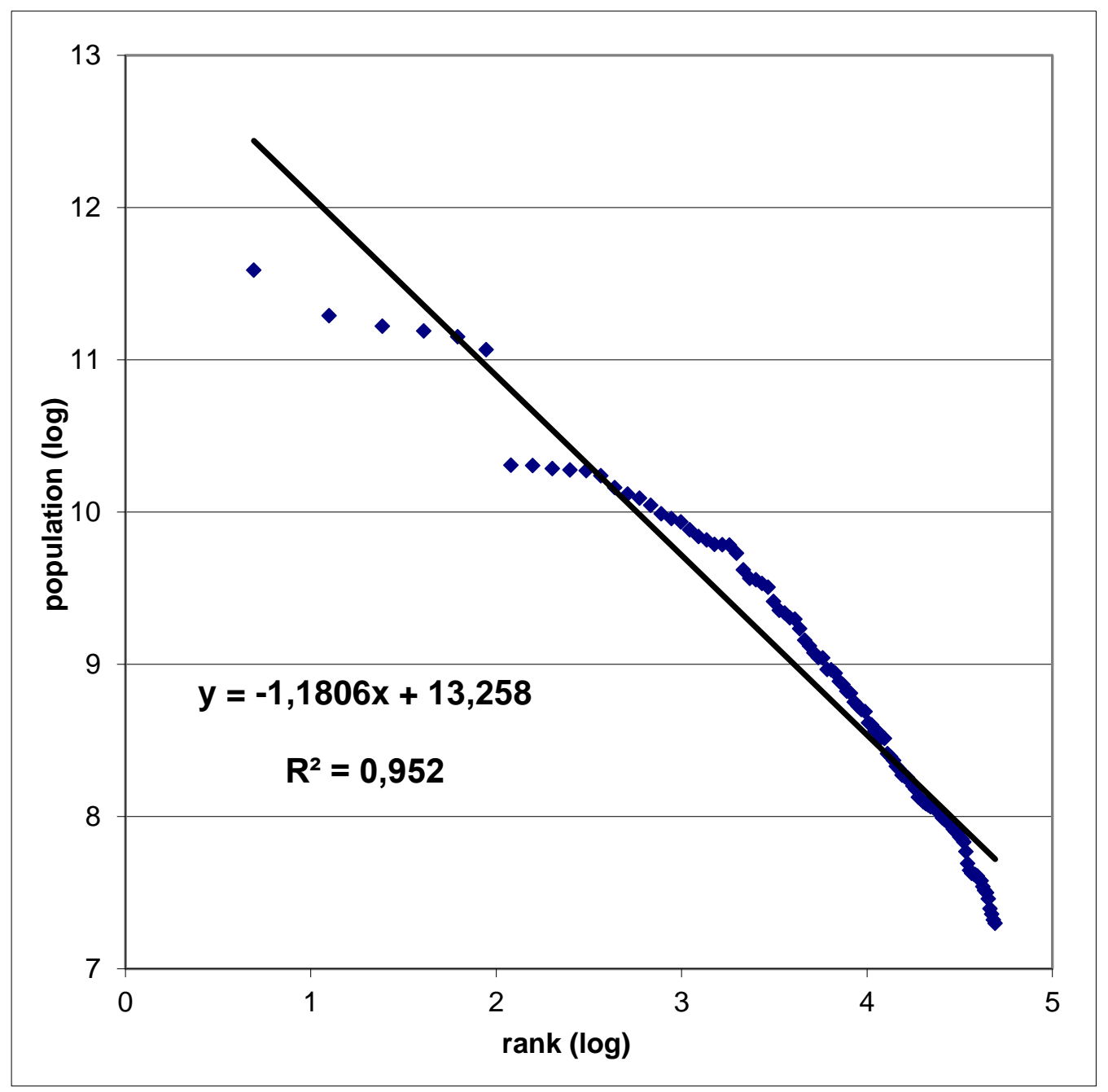

Fig 1. Rank-size distribution of towns in Wielkopolska. Source: own compilation on the basis of the Central Statistical Office 


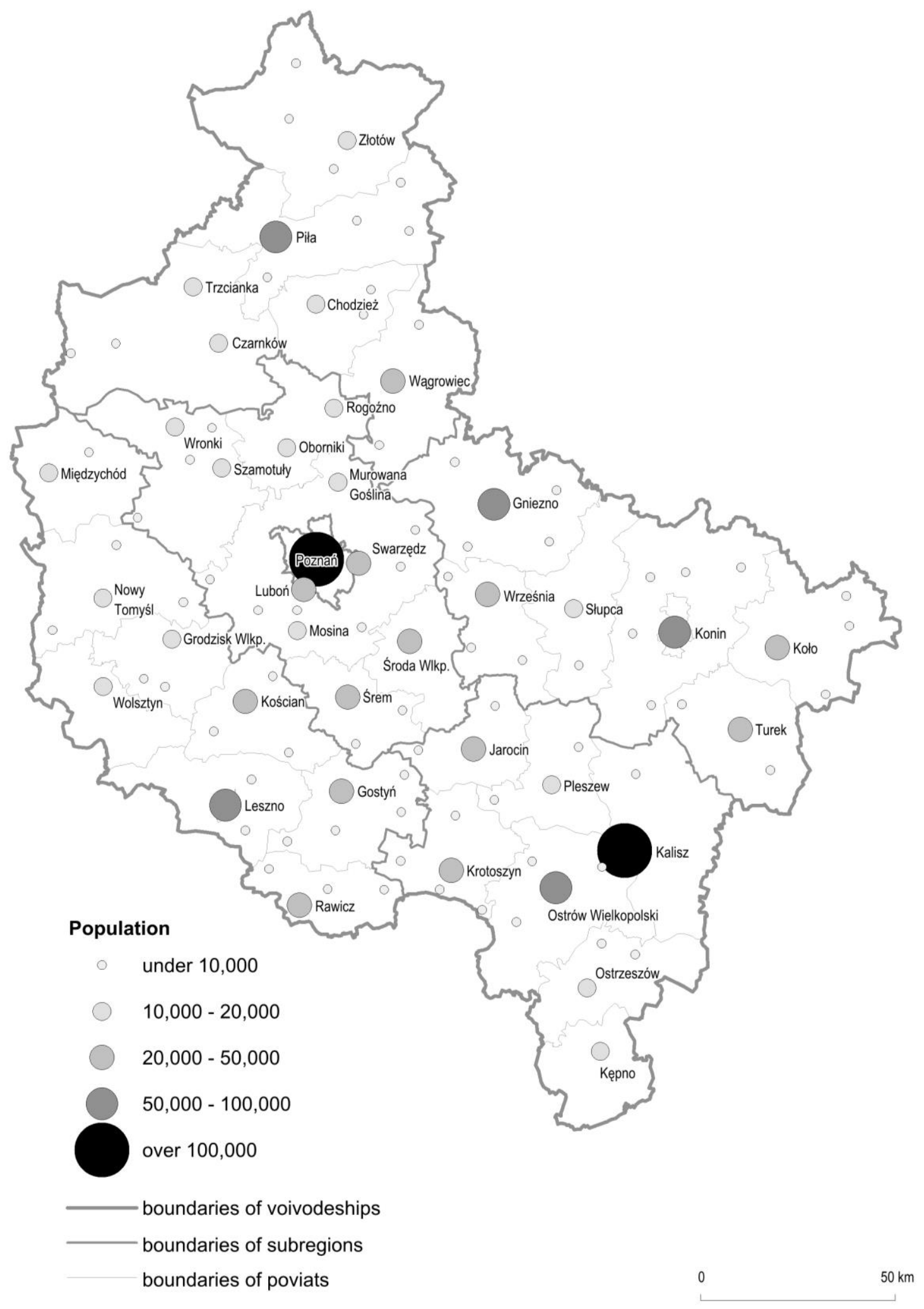

Fig 2. The distribution and size of Wielkopolska towns. Source: own compilation

The hierarchy of Wielkopolska towns reflects Poland's three-tier administrative division in force since 1 January 1999. Standing out are the voivodeship core as well as the poviat and commune centres. The most important administrative functions are performed by Poznań, the voivodeship capital and the seat of local-government /central government authorities. The second tier consists of 35 poviats, including 4 poviat-ranking cities: Poznań, Kalisz, Konin, and Leszno. The other 31 are non-municipal poviats with seats in both, big cities as well as medium-sized and often small ones. It should be emphasised that owing to the considerable 
'excess' of small towns and a 'deficit' of medium-sized ones (in the population interval of 20 100 thousand), small towns with 10 - 20 thousand residents are also administrative seats of second-tier units, i.e. poviats. In Wielkopolska 14 small towns perform the function of poviat centres, including two such centres in one Czarnków-Trzcianka poviat (Trzcianka, Czarnków).

\section{Changes in the population situation of Wielkopolska towns}

An analysis of population change in the towns of Wielkopolska voivodeship was conducted for the years 2000 - 2014 and additionally in three 5-year subperiods: 2000 - 2004, 2005 - 2009 and 2010 - 2014. The set of towns was divided into several size classes (Table 3). Over the entire study period population change was regressive in the following size categories: in big $(93.7 \%)$ and larger medium-sized towns (98.2\%) as well as in small towns with 5 to 10 thousand inhabitants (98.1\%) and the smallest ones with up to 2 thousand $(90.4 \%)$. The population number shows some stabilisation in small towns performing the function of poviat capitals $(99.7 \%)$. Population change took an opposite direction - was progressive in nature - in larger medium-sized towns (102.9\%) and in two classes of small ones: those with a population of 10 to 20 thousand (104.4) and 2 to 5 thousand (108.0\%). The highly favourable situation of units in this last class resulted from a great rotation taking place here, e.g. between 2000 and 2014 four towns joined this class (two because of an increase in population to more than 2 thousand, one because of a population loss to less than 5 thousand, and one that had received municipal rights), and two left this class (one because of an increase in population to more than 5 thousand and another because of a population loss to less than 2 thousand).

The nature of population change in the 5-year subperiods examined differs in individual size classes and does not always follow the general tendency for the entire period. This is mostly due to such factors as periodic population gains and losses that do not cause a change in a town's membership of a given size class, a change in the size of classes as a result of towns moving to other, neighbouring classes caused by a population gain or loss, and the granting of municipal rights.

It should be emphasised that in the case of small towns, irrespective of their size, the factor that significantly affected their population gain over the entire study period $2000-2014(111.3 \%)$ and in the subperiods distinguished was the geographical location in the Poznan agglomeration (Matykowski and Konecka-Szydłowska 2005).

Tab 3. Dynamics of population change in the set of Wielkopolska towns in the years 2000 - 2014 and subperiods 2000 - 2004, 2005 - 2009 and 2010 - 2014.

\begin{tabular}{|l|r|r|r|r|r|}
\hline groups of towns & 2000-2004 & 2005-2009 & 2010-2014 & 2000-2014 & $\begin{array}{c}\text { population } \\
\text { gain/loss, } \\
2000-2014\end{array}$ \\
\hline big, pop. over 100 thousand & 98.2 & 97.7 & 98.2 & 93.7 & $-43,305$ \\
\hline medium-sized, pop. 50-100,000 & 99.8 & 99.4 & 99.1 & 98.2 & $-6,479$ \\
\hline medium-sized, pop. 20-50,000 & 101.1 & 100.8 & 99.5 & 102.9 & $+9,745$ \\
\hline small, pop. 10-20,000 & 99.9 & 99.6 & 99.1 & 104.4 & $+11,147$ \\
\hline small, pop. 5-10,000 & 101.0 & 101.5 & 100.7 & 98.1 & $-2,956$ \\
\hline small, pop. 2-5,000 & 100.5 & 102.5 & 101.0 & 108.0 & $+9,802$ \\
\hline small, pop. up to 2,000 & 99.9 & 90.2 & 111.7 & 90.4 & $-1,857$ \\
\hline small, performing poviat functions & 98.8 & 99.3 & 98.8 & 99.7 & -593 \\
\hline small, in Poznań agglomeration & 102.3 & 103.2 & 102.5 & 111.3 & $+7,269$ \\
\hline
\end{tabular}

Source: own calculations on the basis of the Central Statistical Office data 


\section{Types of population development}

The state of development of the population of Wielkopolska towns results from differences in their rates of natural increase and in net migration. Webb's (1964) typology of demographic regimes allows assigning the towns to one of eight classes, and on this basis determining the role of natural increase and migration movement in their natural change.

At the start of the study period, i.e. in 2002, most of the 109 Wielkopolska towns belonged to the development types A to D: 59 towns, i.e. 54\%, while in 1992 this was $78 \%$ (Weltrowska and Konecka-Szydłowska 2006). The most numerous was type B with a positive rate of natural increase surpassing the net migration inflow (18 towns). 50 towns belonged to a depopulation type, from $\mathrm{F}$ to $\mathrm{H}$. Most towns represented type $\mathrm{H}$, with a net migration outflow exceeding a positive rate of natural increase. The chief city of the voivodeship, Poznań, turned out to belong to type $\mathrm{F}$, with a negative rate of natural increase exceeding a net migration outflow. In 2008, towns of the development types still predominated slightly, at $51 \%$ (56 towns). This time the most frequent were types $A$ and $B$ (20 towns each), with a positive rate of natural increase higher than the net migration outflow or inflow. The number of depopulation-type units grew to 53, with type $\mathrm{H}$ invariably predominant (43 towns). The city of Poznań also belongs to this type and represents an emigration centre. At the end of the study period, i.e. in 2014, the tendency prevailing so far turned out to have reversed. The depopulation type clearly started to dominate, with 68 towns (62\%). As in the previous years, decidedly the most numerous was depopulation type $\mathrm{H}$ (with Poznań still in it). The number of development-type units dropped to 41 , with the predominance of towns of type A.

An analysis of the 2002-2014 pattern of change in the small Wielkopolska towns assigned to population types shows that the tendencies observed in this subset were similar to those in the entire set, i.e. there was a clear decline in the proportion of units representing development types, from $44 \%$ in 2000 to $38 \%$ in 2014. Depopulation was characteristic of towns of all size categories, this tendency being also shown by many large and medium-sized Polish cities (Gadziński and Męczyński 2011; Runge, 2013). However, what is significant is that in small Wielkopolska towns the dynamics of this process was lower than in the case of the remaining towns of the region (Table 4, Fig. 3).

Tab 4. Proportion of Wielkopolska towns of Webb's development types $(A-D)$ and depopulation types $(E-H)$.

\begin{tabular}{|l|c|c|c|c|c|c|}
\hline \multirow{2}{*}{ towns } & \multicolumn{2}{|c|}{2002} & \multicolumn{2}{c|}{2008} & \multicolumn{2}{c|}{2014} \\
\cline { 2 - 7 } & $\begin{array}{c}\text { types } \\
\text { A-D }\end{array}$ & $\begin{array}{c}\text { types } \\
\text { E-H }\end{array}$ & $\begin{array}{c}\text { types } \\
\text { A-D }\end{array}$ & $\begin{array}{c}\text { types } \\
\text { E-H }\end{array}$ & $\begin{array}{c}\text { types } \\
\text { A-D }\end{array}$ & $\begin{array}{c}\text { types } \\
\text { E-H }\end{array}$ \\
\hline total & 54 & 46 & 51 & 49 & 38 & 62 \\
\hline big and medium-sized towns & 55 & 45 & 45 & 55 & 30 & 70 \\
\hline small towns & 44 & 56 & 43 & 57 & 39 & 61 \\
\hline
\end{tabular}

$A-D$ development types, $E-H$ depopulation types

Source: own calculations on the basis of the Central Statistical Office data

In 2002 small towns mostly represented development type D, with a net migration inflow exceeding a negative rate of natural increase (15 towns), and depopulation type $\mathrm{H}$ (20 towns). In 2008 the development types that predominated were A (17) and B (16), which means that the chief factor in natural change was a positive rate of natural increase, while in the depopulation group type $\mathrm{H}$ (33) had gained in importance. In 2014 the dominant development type was $C$ (15), characterised by net in-migration exceeding the natural increase. Predominating among depopulation types was still type $\mathrm{H}(41)$, while depopulation type $\mathrm{G}$ with net out-migration exceeding the natural decrease gained in significance (15) (Table 5, Fig. 3).

In 2014 the population had grown in only $39 \%$ of small towns. This means an increasing number of Wielkopolska towns experiencing depopulation (as many as $68 \%$ of towns with 2 5 thousand residents). Natural increase, which usually did not recompense for net migration outflows, was positive in most small towns of the region $(75 \%)$, while a net migration inflow was observed in only $26 \%$. 


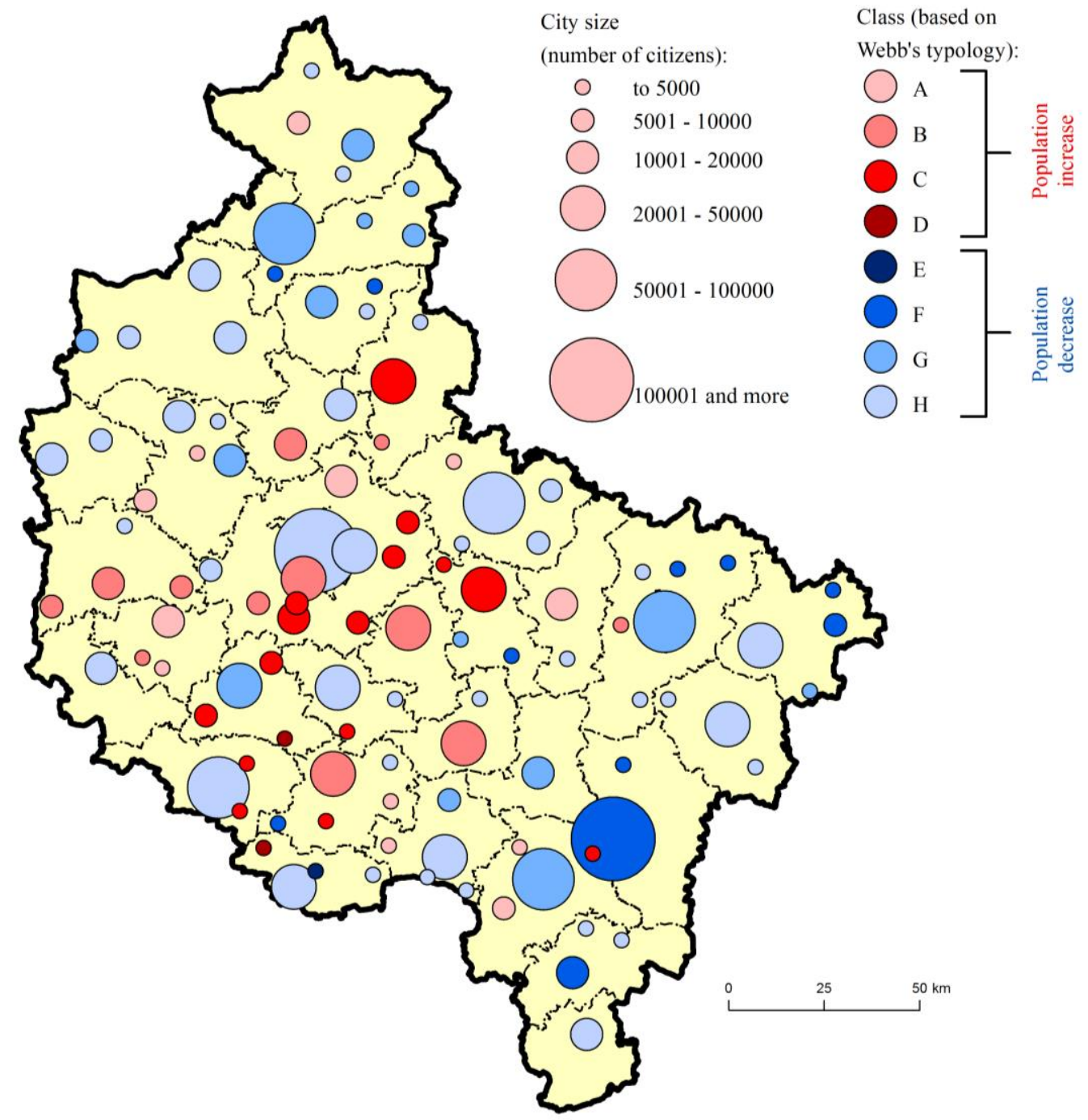

Fig 3. Population types of towns of Wielkopolska voivodeship in 2014 in terms of Webb classes. Source: own compilation on the basis of the Central Statistical Office

Tab 5. Population development types of small towns in Wielkopolska voivodeship in 2014.

\begin{tabular}{|l|c|c|c|c|c|}
\hline \multicolumn{1}{|c|}{ type } & $\begin{array}{c}\text { total small } \\
\text { towns }\end{array}$ & $\begin{array}{c}\text { towns with up } \\
\text { to 2,000 pop. }\end{array}$ & $\begin{array}{c}\text { towns with 2- } \\
5,000 \text { pop. }\end{array}$ & $\begin{array}{c}\text { towns with 5- } \\
10,000 \text { pop. }\end{array}$ & $\begin{array}{c}\text { towns with 10- } \\
20,000 \text { pop. }\end{array}$ \\
\hline $\mathrm{A}\left(\mathrm{PN}_{+}>|\mathrm{SM}-|\right)$ & 12 & 2 & 4 & 3 & 3 \\
\hline $\mathrm{B}\left(\mathrm{PN}_{+}>\mathrm{SM}_{+}\right)$ & 8 & 0 & 3 & 3 & 2 \\
\hline $\mathrm{C}\left(\mathrm{PN}_{+}<\mathrm{SM}_{+}\right)$ & 13 & 1 & 5 & 6 & 1 \\
\hline $\mathrm{D}\left(|\mathrm{PN}-|<\mathrm{SM}_{+}\right)$ & 2 & 1 & 1 & 0 & 0 \\
\hline $\mathrm{E}\left(|\mathrm{PN}-|>\mathrm{SM}_{+}\right)$ & 1 & 0 & 1 & 0 & 1 \\
\hline $\mathrm{F}(|\mathrm{PN}-|>|S M-|)$ & 10 & 2 & 6 & 3 & 4 \\
\hline $\mathrm{G}(|\mathrm{PN}-|<|S M-|)$ & 13 & 0 & 4 & 5 & 7 \\
\hline $\mathrm{H}(\mathrm{PN}+<|S M-|)$ & 32 & 4 & 16 & 21 & 18 \\
\hline total & 89 & 10 & 40 & & 3 \\
\hline
\end{tabular}

$P N$ - natural increase, SM - net migration

Source: own calculations on the basis of the Central Statistical Office data 
It should be emphasised that despite the tendency observed among small Wielkopolska towns for depopulation types to increase at the cost of development ones, their population situation is relatively much more favourable than in the other regions. In the years 2010 - 2012 the proportion of small Wielkopolska towns belonging to a development type was the highest, at $46 \%$, the mean for small towns in Poland being $28 \%$. The voivodeships with the worst situation were Lubuska Land and Świętokrzyska Land, in which more than $90 \%$ of small towns represented a depopulation type (Kwiatek-Sołtys, 2015).

\section{Population situation of the small towns of the Poznan agglomeration}

In comparison with the small towns of the Wielkopolska region, those in the Poznań agglomeration (incorporated in 1999 into Poznań poviat) stand out for their higher level of development of the population, economy and housing. The poorest developed is social infrastructure, which follows indirectly from the fact that various services in this field are available in Poznan. Broader analyses of the socio-economic situation of the small towns of the agglomeration have been made, among others, by Konecka-Szydłowska (2006, 2014), Zuzańska-Zyśko (2007), Churski, Konecka-Szydłowska and Perdał (2009), Kaczmarek (ed.) 2010, Męczyński, Konecka-Szydłowska and Gadziński (2010), and Korzeniak (ed.) (2014).

In 2014 the Poznań agglomeration, i.e. the city of Poznań and its suburban zone (Poznań poviat), was inhabited by 904.5 thousand people, or 61.8 thousand more than in 2000 (the dynamics index $107.3 \%$ ). This rise was due to an increase in population in the suburban zone, including the towns located here, which is connected with the process of suburbanisation. This meant a decline in the proportion of residents of the central city in relation to those of the suburban zone: in 2000 Poznań was inhabited by $69 \%$ of all people living in the analysed area, and in 2014 this figure dropped to $60 \%$. In the years $2002-2014$ the small towns located in the agglomeration had high rates of population change (the dynamics index of $111.3 \%$ ), which boosted their population by more than 7 thousand. The highest values of the dynamics index, over $110.0 \%$, were recorded in Kostrzyn, Kórnik, Pobiedziska and Stęszew, and the lowest in Buk, 99.1\% (Table 6).

Tab 6. Population of the Poznań agglomeration in 2000 and 2014.

\begin{tabular}{|c|c|c|c|}
\hline \multirow[b]{2}{*}{ unit } & \multicolumn{2}{|c|}{ population } & \multirow{2}{*}{$\begin{array}{l}\text { dynamics index } \\
2000-2014 \text { in \% }\end{array}$} \\
\hline & 2000 & 2014 & \\
\hline Poznań and suburban zone (Poznań poviat) & 842,772 & 904,574 & 107.3 \\
\hline Poznań city & 582,254 & 545,680 & 93.7 \\
\hline Suburban zone & 260,518 & 358,894 & 137.8 \\
\hline $\begin{array}{l}\text { of which: } \\
\text { towns in suburban zone }\end{array}$ & 116,080 & 133,702 & 115.2 \\
\hline small towns in suburban zone & 64,585 & 71,854 & 111.3 \\
\hline
\end{tabular}

Source: own compilation on the basis of the Local Data Bank and the Central Statistical Office

The structure of population change of the small towns in the Poznan agglomeration can be described by population types. In 2002 they belonged exclusively to development types $A$ to $D$ in Webb's (1964) typology of demographic regimes, characterised by a population increase (Table 7). A similar tendency was recorded in the successive years. In 2012 only two towns: Buk (a great outflow of the population to the rural commune) and Puszczykowo (an ageing community, with a negative rate of natural increase), had a slight drop in the population figure and belonged to depopulation types $\mathrm{H}$ and $\mathrm{E}$. In 2014 a development type still predominated among the towns of the agglomeration, especially type $C$ with net in-migration. Depopulation type $\mathrm{H}$ was only found in Buk, which kept losing inhabitants owing to net out-migration. 
Tab 7. Population situation in the small towns of the Poznań agglomeration.

\begin{tabular}{|c|c|c|c|c|c|}
\hline \multirow{2}{*}{ town } & \multirow{2}{*}{2002} & \multirow{2}{*}{2014} & \multirow{2}{*}{$\begin{array}{c}\text { index of } \\
\text { population } \\
\text { dynamics (\%) }\end{array}$} & \multicolumn{2}{|c|}{$\begin{array}{l}\text { type of demographic regime, } \\
\text { after Webb, in } 2002 \text { and } 2014\end{array}$} \\
\hline & & & & 2002 & 2014 \\
\hline Buk & 6,244 & 6,188 & 99.1 & A & $\mathrm{H}$ \\
\hline Kostrzyn & 8,276 & 9,542 & 115.3 & $\mathrm{D}$ & C \\
\hline Kórnik & 6,485 & 7,684 & 118.5 & C & $\mathrm{C}$ \\
\hline Mosina & 12,027 & 13,220 & 109.9 & $\mathrm{D}$ & C \\
\hline $\begin{array}{l}\text { Murowana } \\
\text { Goślina }\end{array}$ & 9,910 & 10,424 & 105.2 & B & A \\
\hline Pobiedziska & 8,065 & 9,091 & 112.7 & $\mathrm{D}$ & C \\
\hline Puszczykowo & 9,036 & 9,802 & 108.5 & $\mathrm{D}$ & $\mathrm{C}$ \\
\hline Stęszew & 5,176 & 5,903 & 114.0 & $A$ & $\mathrm{~B}$ \\
\hline
\end{tabular}

Source: own compilation on the basis of the Local Data Bank and the Central Statistical Office

\section{Significance of new towns in the urbanisation of Wielkopolska voivodeship}

In the years 1989 - 2016, i.e. since the start of the socio-economic transformation in Poland, the size of the set of Polish towns has been changing almost yearly. Their number grew from 822 in 1989 to 919 in 2016 (in 2002 the town of Wesoła was incorporated into Warsaw's administrative boundaries), which means that 98 localities had received municipal rights over that time. In a decided majority of cases (over $70 \%$ ) this was the restitution of municipal rights to units that used to be towns once (Drobek, 2002; Szymańska, 1996; Szmytkie and Krzysztofik 2011; Zaniewska et al. 2013; Sokołowski, 2014; Krzysztofik and Dymitrow 2015). Newlyestablished towns account for a considerable proportion of the country's urban settlement network because they make up $11 \%$ of the total number. This is a figure which proves that the transformation period has been one of the most crucial ones in urban development in Poland over the last 800 years (Krzysztofik, 2005). The spatial distribution of the new towns established in the years 1989 - 2016 is not regular. They clearly concentrate in the southeastern part of Poland, in the voivodeships of Silesia, Małopolska (12 in each), Lublin (10), as well as Mazovia and Świętokrzyska Land (9 in each).

Seen against the country's regional system, Wielkopolska belongs to voivodeships with a low level of municipalisation. In the years 1989 - 2016 municipal rights were restituted to five units here: Obrzycko (1990), Nekla (2000), Dobrzyca (2014), Chocz (2015), and Jaraczewo (2016). The creation of those new towns caused the density of towns in the voivodeship to increase slightly, from 3.6 per $1,000 \mathrm{~km}^{2}$ in 1989 to 3.8 in 2016 . The new towns account for $4.5 \%$ of all towns in Wielkopolska and for a mere $0.7 \%$ (12.5 thousand) of its urban population. In terms of size, the new towns belong to the class of small ones. Their mean population is only 2.5 thousand, lower than the average for the entire set of towns restituted in Poland, which is 2.7 thousand (Konecka-Szydłowska, 2015).

The importance of new towns in the urbanisation of Wielkopolska as a region is small, but greater at the level of local districts, i.e. poviats. Here the new towns account for from $4.8 \%$ of the urban population (Jarocin poviat) to $15.1 \%$ (Pleszew poviat), thus significantly raising the total level of urbanisation and the total number of towns in poviats (Table 8). 
Tab 8. New towns in Wielkopolska established in the years 1989 - 2016.

\begin{tabular}{|c|c|c|c|c|c|c|}
\hline$\sum_{3}^{0}$ & . & 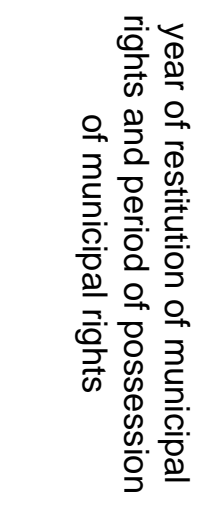 & 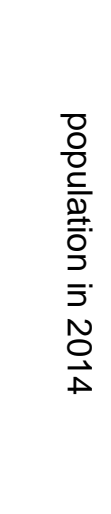 & 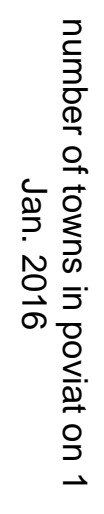 & 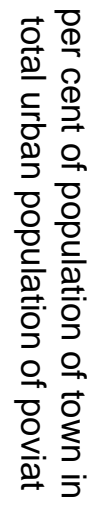 & 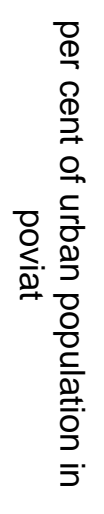 \\
\hline Obrzycko & szamotulski & $\begin{array}{r}1990 \\
1638-1934\end{array}$ & 2,393 & 5 & 5.6 & 47.5 \\
\hline Nekla & wrzesiński & $\begin{array}{r}2000 \\
1725-1793\end{array}$ & 3,665 & 4 & 9.1 & 52.3 \\
\hline Dobrzyca & pleszewski & $\begin{array}{r}2014 \\
1440-1934\end{array}$ & 3,167 & 3 & 15.1 & 35.8 \\
\hline Chocz & pleszewski & $\begin{array}{r}2015 \\
\text { XIV. }-1870\end{array}$ & 1,812 & 3 & 8.6 & 35.8 \\
\hline Jaraczewo & jarociński & $\begin{array}{r}2016 \\
1519-1934\end{array}$ & 1,450 & 3 & 4.8 & 41.8 \\
\hline
\end{tabular}

Source: own compilation on the basis of Central Statistical Office data

\section{Conclusions}

The conducted analysis of the significance of small towns in the urbanisation of Wielkopolska voivodeship - characterised by a high level of urbanisation as measured by the total number of towns, but with a relatively low proportion of the urban population - shows that its urban settlement network is in a state of balance. Population losses occurring in some size categories of towns are made up by population gains in other size categories. A characteristic feature of the population change taking place in the set of Wielkopolska towns, as in other Polish agglomerations, is the depopulation of its core city, Poznań, accompanied by an increase in the population of small units located in its suburban zone. There is an upward tendency in the population number also in selected size classes of small towns, which demonstrates that in this case we cannot speak of a crisis of small towns, which play an important role in the urbanisation of Wielkopolska voivodeship. In the recent years, increasingly important in this process, especially at the local level, has been the appearance of new towns set up as a result of the restitution of municipal rights.

In sum, it can be stated that what distinguishes Wielkopolska voivodeship from other Polish regions is its high level of urbanisation connected with its great number of, mostly small, towns and with a relative stabilisation of the population of those small towns. In Wielkopolska there is a growing number of towns belonging to a depopulation type, but it should be emphasised that here the rate of this process is slower than in other regions. In small towns lying outside the Poznań agglomeration the predominant component of population change is net outmigration, while those in the agglomeration record net in-migration. An increase in the population number, or the urbanisation of the small towns of the agglomeration, so to speak, is connected with suburbanisation processes and partly with the de-urbanisation of the central city (Gaebe 2004). However, on the assumption that an agglomeration is a compact and consistent whole with a relatively extensive spatial range, depopulation does not occur here (Rerat 2012). 
Studies of the urban development model published in the 1980s that assumed four stages of urban development: urbanisation, suburbanisation, de-urbanisation and re-urbanisation (Klaassen, Molle, Paelinck 1981, Regulski 1982), showed that those processes differed in Europe. Urbanisation dominated until the 1950s, while the 1960s were a period of suburbanisation and the 1970s, of de-urbanisation. It should be stressed, however, that in the countries of the so-called Eastern block suburbanisation and de-urbanisation stages came later than in the West European states (Zasin 2015). In the Polish conditions, intensive suburbanisation processes can be observed since the 1990s and today they coincide with those of de-urbanisation (Parysek 2008, Heffner 2016). Klaassen's model assumed the appearance of a fourth stage in urban development, viz. re-urbanisation, which made it different from Gibbs' model (Rerat 2012, Zasin 2015). Today re-urbanisation connected with an increase in the population of a city, especially in its central parts, can mostly be observed in West European towns, e.g. French (Ogden, Hall 2000), Swiss (Rerat 2012) or selected German ones (an interesting case of Leipzig, cf. Haase et al. 2009, Paszkuć 2015).

Korcelli (2007) claims that, given the metropolitanisation of space, demographic regression and mass emigration can threaten the operation of the settlement system at its lower levels, i.e. regional and local (in Poland). Assuming that economic development at the scale of the country depends to a great extent on the rank and competitiveness of its chief urban centres, the concentration of development processes only in those centres reinforces detrimental changes and causes a further weakening of the cohesion of the polycentric spatial system. Metropolitanisation leads to a polarisation of space (with dynamically developing agglomeration areas and stagnating peripheries), which is a fundamental problem of a modern spatial policy. Some symptoms of this process can be observed in the set of small Wielkopolska towns, which can contribute to the weakening of the spatial cohesion of the urban settlement network of the voivodeship in a longer perspective.

According to Korcelli (2007), Poland's spatial policy should recognise the role of small towns, especially poviat ones (Benedyk, 2014), and the significance of keeping up and strengthening their function in the spatial organisation of social life. The reconstruction and maintenance of the economic potential of small towns should rest primarily on their endogenous resources. It is also necessary to support voivodeship self-government in its efforts to encourage local communities and local development institutions to take initiatives for the development of their towns and cooperation with large urban units. Promoting small towns as local growth /sustainable development centres using their endogenous potential has also been emphasised by ESPON in one of its three scenarios of Europe's development until 2050 (ESPON, 2014).

References

[1] Area and population in the territorial pattern in 2015, Warsaw: Central Statistical Office.

[2] Benedyk, E. (2014). Sorry, taki mamy model (pp. 59-61). Niezbędnik Inteligenta. Miasta i Ludzie, Warszawa: Polityka.

[3] Burdack, J. \& Kriszan, A., eds. (2013). Kleinstädte in Mittel-und Osteuropa: Perspektiven und Strategien lokaler Entwicklung, Leipzig: Leibniz-Institut für Länderkunde.

[4] Churski, P., Konecka-Szydłowska, B. \& Perdał, R. (2009). Rola aglomeracji miejskiej Poznania w kształtowaniu spójności regionu wielkopolskiego (pp. 1-55). In Churski, P., ed., Spójność i konkurencyjność regionu wielkopolskiego [Research Report]. Poznań: Adam Mickiewicz University.

[5] Czyż, T. (2000). Zróżnicowanie wymiaru ludnościowo-urbanizacyjnego nowych województw, Przegląd Geograficzny, 72(4), 447-465.

[6] Drobek, W. (2002). Polskie nowe miasta (1977 - 2001), (pp. 71-84). In Słodczyk, J., ed., Przemiany bazy ekonomicznej i struktury funkcjonalnej miast. Opole: Wydawnictwo Uniwersytetu Opolskiego. 
[7] Making Europe Open and Polycentric. Vision and Scenarios for the European Territory towards 2050. 2013.2 RSPON 2 Retrieved http://www.yumpu.com/en/document/view/37765912/espon-vision-scenarios-2050/28. Accessed at 15.5.2016.

[8] Gadziński, J. \& Męczyński, M. (2011). Investing in urban sustainable development in Poland. Territorial diagnosis of competitiveness of urban areas in Poland. Poznań: Bogucki Wydawnictwo Naukowe.

[9] Gaebe, W. (2004). Urbane Räume. Stuttgart: UTB GmbH.

[10] Gibbs, J. P. (1963). The evolution of population concentration. Economic Geography 39(2), 119-129. DOI: $10.2307 / 142505$.

[11] Haase, A. et al., (2009). Emergent spaces of reurbanisation: Exploring the demographic dimension of inner-city residential change in a European setting. Population, Space and Place 16(5), 443-463. DOI: 10.1002/psp.603.

[12] Heffner, K. (2008). Funkcjonowanie miast małych w systemie osadniczym Polski w perspektywie 2033 r. (pp. 281-233). In Saganowski, K., Zagrzejewska-Fedorowicz, M. \& Zuber, P, eds., Ekspertyzy do Koncepcji Przestrzennego Zagospodarowania Kraju do roku 2033. Warszawa: Ministerstwo Rozwoju Regionalnego.

[13] Heffner, K. (2016). Proces suburbanizacji a polityka miejska w Polsce (pp. 75-110). In Marszał, T., ed., Miasto - region - gospodarka w badaniach geograficznych. W stulecie urodzin Profesora Ludwika Straszewicza. Łódź: Wydawnictwo Uniwersytetu Łódzkiego.

[14] Jakóbczyk-Gryszkiewicz, J. (2012). Procesy urbanizacji (pp. 175-206). In Liszewski, S., ed., Geografia urbanistyczna. Warszawa: Wydawnictwo Naukowe PWN.

[15] Jaroszewska, E. \& Stryjakiewicz, T. (2014). Kurczenie się miast w Polsce (pp. 67-77). In Stryjakiewicz, T., ed., Kurczenie się miast w Europie Środkowo-Wschodniej, Poznań: Bogucki Wydawnictwo Naukowe.

[16] Jażdżewska, I. (2006). Związek między podziałem administracyjnym a miejską siecią osadniczą Polski. Zastosowanie metody k-średnich do badań miejskiej sieci osadniczej, Przegląd Geograficzny, 78(2), 247-259.

[17] Kaczmarek, T., ed. (2010). Ilustrowany Atlas Aglomeracji Poznańskiej. Poznań: Bogucki Wydawnictwo Naukowe.

[18] Klaassen, L. H., Molle, W. T. M. \& Paelinck J. H. P., eds. (1981). Dynamics of Urban Development. Farnbourough: Gower.

[19] Konecka-Szydłowska, B. (2003). Rozwój społeczno-gospodarczy Nowego Tomyśla w okresie transformacji systemowej. Poznań: Bogucki Wydawnictwo Naukowe.

[20] Konecka-Szydłowska, B. (2006). Sytuacja społeczno-gospodarcza miast strefy podmiejskiej Poznania w okresie transformacji (pp. 113-127). In Słodczyk, J. \& Klimek, R., eds., Przemiany przestrzeni miast i stref podmiejskich. Opole: Uniwersytet Opolski.

[21] Konecka-Szydłowska, B. (2009). System miast województwa wielkopolskiego (pp. 9-20). In Czyż, T., ed., Regionalny wymiar województwa wielkopolskiego. Poznań: Adam Mickiewicz University.

[22] Konecka-Szydłowska, B. (2011). Małe miasta nowo utworzone w procesie urbanizacji (pp. 9-25). In Bartosiewicz, B. \& Marszał, T., ed., Przemiany przestrzeni i potencjału małych miast $w$ wybranych regionach Polski-z perspektywy 20 lat transformacji, Łódź: Wydawnictwo Uniwersytetu Łódzkiego.

[23] Konecka-Szydłowska, B. (2014). Socio-economic situation of small towns of the Poznań agglomeration (pp. 133-146). In Kwiatek-Sołtys, A., Mainet, H., Widermann, K. \& Edouard, J.-C., eds., Small and medium towns' attractiveness at the beginning of the $21^{\text {st }}$ century. Clermont-Ferrand: Presses Universitaires Blasise Pascal. 
[24] Konecka-Szydłowska, B. (2015). Restituted towns and their socio-economic conditions for development (pp. 117-138). In Krzysztofik, R. \& Dymitrow, M., eds., Degraded and restituted towns in Poland: Origins, development, problems. Göteborg: University of Gothenburg.

[25] Konecka-Szydłowska, B., Zuzańska-Żyśko, E. \& Szmytkie, R. (2010). Role of services in the economies of small towns of Silesia region and Wielkopolskie voivodship. Bulletin of Geography. Socio-economic Series 14, 51-62, DOI: 10.2478/v10089-010-0014-1.

[26] Korcelli, P. (2007). Podstawowe węzły układu osadniczego Polski na tle europejskiego systemu osadniczego (aglomeracje-metropolie), Biuletyn Komitetu Przestrzennego Zagospodarowania Kraju 233, 87-113.

[27] Korzeniak, G., ed. (2014). Małe i średnie miasta w policentrycznym rozwoju Polski. Kraków: Instytut Rozwoju Miast.

[28] Krzysztofik, R. (2005). Proces kształtowania się sieci miejskiej w Polsce w okresie od XIII do XX wieku. Czasopismo Geograficzne 76(4), 383-393.

[29] Krzysztofik, R. (2006). Nowe miasta w Polsce w latach 1980 - 2009. Geneza i mechanizmy rozwoju, Próba typologii. Sosnowiec: Uniwersytet Śląski.

[30] Krzysztofik, R. \& Dymitrow, M., eds. (2015). Degraded and restituted towns in Poland: Origins, development, problems. Göteborg: University of Gothenburg.

[31] Kühn, M. (2015). Small towns in peripheral regions of Germany. Annales Universitatis Paedagogicae Cracoviensis, Studia Geographica 8, 29-38.

[32] Kwiatek-Sołtys, A. (2004). Małe miasta województwa małopolskiego w okresie transformacji systemowej. Kraków: Wydawnictwo Naukowe Akademii Pedagogicznej.

[33] Kwiatek-Soltys, A. (2015). Population changes as litmus paper of the socio-economic development level of small towns in Poland, Annales Universitatis Paedagogicae Cracoviensis, Studia Geographica 8, 39-53.

[34] Leetmaa, K., Nuga, M. \& Org, A. (2013). Entwicklungsstrategien und soziales Kapital in den schrumpfenden Kleinstädten Südestlands (pp. 31-52). In Burdack, J. \& Kriszan, A., eds., Kleinstädte in Mittel-und Osteuropa: Perspektiven und Strategien lokaler Entwicklung. Leipzig: Leibniz-Institut für Länderkunde.

[35] Maik, W. (1992). Podstawy geografii miast. Toruń: Uniwersytet Mikołaja Kopernika.

[36] Mainet, H. (2015). The paradoxical place of small towns in sustainable development policies. What is beyond the images of "places where the living is easy"? Annales Universitatis Paedagogicae Cracoviensis, Studia Geographica 8, 5-11.

[37] Matykowski, R. \& Konecka-Szydłowska, B. (2005). Procesy urbanizacji w Wielkopolsce oraz w strefie podmiejskiej Poznania (pp. 153-162). In Jażdżewska, I., ed., XVIII Konwersatorium Wiedzy o Mieście. Współczesne procesy urbanizacji i ich skutki. Łódź: Uniwersytet Łódzki.

[38] Męczyński, M., Konecka-Szydłowska, B. \& Gadziński, J. (2010). Poziom rozwoju społeczno-gospodarczego i klasyfikacja małych miast Wielkopolski [Expertise]. Poznań: Urzęd Marszałkowski.

[39] Najgrakowski, M. (2009). Miasta Polski do początku XXI wieku. Warszawa: Institute of Geography and Spatial Organization PAN.

[40] Ogden, P. E. \& Hall, R. (2000). Households, reurbanisation and the rise of living alone in the principal French cities, 1975 - 1990. Urban Studies 37(2), 367-390. DOI: $10.1080 / 0042098002230$.

[41] Pacione, M. (2005). Urban geography. A global prospective. London, New York: Routledge. 
[42] Parysek, J. (2008). Suburbanizacja i dezurbanizacja: Dwa bieguny polskiej urbanizacji (pp. 261-286). In Parysek, J. \& Stryjakiewicz, T., eds., Region społeczno-ekonomiczny i rozwój regionalny. Poznań: Bogucki Wydawnictwo Naukowe.

[43] Paszkuć, K. (2015). Functioning of small towns in agglomeration areas-exemple of Poznań and Leipzig agglomerations. [Unpublished Magister Thesis]. Poznań: Instytut Geografii Społeczno-Ekonomicznej i Gospodarki Przestrzennej Adam Mickiewicz University.

[44] Regulski, J. (1982). Ekonomika miasta. Warszawa: Państwowe Wydawnictwo Ekonomiczne.

[45] Rerat, P. (2012). The new demographic growth of cities: The case of reurbanisation in Switzerland, Urban Studies 49(5), 1107-1125. DOI: 10.1177/0042098011408935.

[46] Runge, A. (2013). Rola miast średnich w kształtowaniu systemu osadniczego Polski. Katowice: Uniwersytet Śląski.

[47] Runge, A. \& Kwiatek-Sołtys, A. (2011). Małe średnie miasta na osi kontinuum osadniczego (pp. 151-162). In Soja, M. \& Zborowski, A., ed., Człowiek w przestrzeni zurbanizowanej. Kraków: Jagiellonian University.

[48] Sokołowski, D. (2014). New towns in Poland. Bulletin of Geography, Socio-Economic Series 23, 149-160. DOI: 10.2478/bog-2014-0010.

[49] Schmidt, J. \& Matykowski, R., eds. (2007). Granica symboliczna i jej pogranicza w czasach najnowszych. Poznań: Awel.

[50] Strategy for the Development of Wielkopolska Voivodeship until 2020 (2012). Poznań: Marshal's Office.

[51] Szmytkie, R. (2014). Metody analizy morfologii i fizjonomii jednostek osadniczych. Wrocław University.

[52] Szmytkie, R. \& Krzysztofik, R. (2011). Idea miejskości w Polsce (pp. 25-38). In Namyślak, B., ed., Przekształcenia regionalnych struktur funkcjonalno-przestrzennych, Zmiany funkcjonalno-przestrzenne miast i obszarów wiejskich. Wrocław: Uniwersytet Wrocławski.

[53] Szymańska, D. (1996). Nowe miasta w systemach osadniczych. Toruń: Wydawnictwo UMK.

[54] Szymańska, D. (2007). Urbanizacja na świecie. Warszawa: Wydawnictwo Naukowe PWN.

[55] Szymańska, D. (2009). Geografia osadnictwa. Warszawa: Wydawnictwo Naukowe PWN.

[56] Szymańska, D. \& Grzelak-Kostulska, E. (2005). Małe miasta w Polsce-zmiany ludnościowe i funkcjonalne w drugiej połowie XX wieku (pp. 59-90). In Heffner, K., ed., Małe miasta a rozwój lokalny i regionalny. Katowice: Wydawnictwo Uczelniane Akademii Ekonomicznej.

[57] Vaishar, A. \& Zapletalová, J. (2009). Small towns as centres of rural micro-regions, European Countryside 1(2), 70-81. DOI: 10.2478/v10091-009-0006-4.

[58] Webb, J. W. (1963). The natural and migrational components of population changes in England and Wales, 1921-1931. Economic Geography, 39(2), 130-148. DOI: $10.2307 / 142506$.

[59] Weltrowska, J. \& Konecka-Szydłowska, B. (2006). Population changes in the towns of Wielkopolska voivodeship. Bulletin of Geography Socio-Economic Series. 5, 21-32.

[60] Węcławowicz, G. (2010). Charakterystyka głównych trendów i zmian w rozwoju obszarów miejskich Polski [Expertise]. Warszawa: Ministerstwo Rozwoju Regionalnego.

[61] Zaniewska, H., Borcz, H., Filipiak-Niedźwiecka, I., Barek, R. \& Thiel, M. (2013). Małe miasta, które uzyskały prawa miejskie w latach 1989-2011. Kraków: Instytut Rozwoju Miast.

[62] Zasina, J. (2015). Reurbanizacja w świetle dotychczasowych badań nad miastami europejskimi. Studia Miejskie 20, 155-166. 
[63] Zipf, G. K. (1949). Human behaviour and the principle of least effort. Cambridge, Mass.: Addison Wesley Press.

[64] Zuzańska-Zyśko, E. (2006). Małe miasta w okresie transformacji. Studium w regionie śląskim. Katowice: Śląskie Wydawnictwo Naukowe.

[65] Zuzańska-Zyśko, E. (2007). Małe miasta w strefie oddziaływania ośrodków regionalnych. Biuletyn Komitetu Przestrzennego Zagospodarowania Kraju PAN 232, 62-78. 